\title{
An overview of articles on Competitive Intelligence in JCIM and CIR
}

\author{
Klaus Solberg Søilen, \\ Halmstad University, \\ School of Business and Engineering \\ SE-301 18 HALMSTAD \\ Sweden
}

klasol@hh.se

Received December 28 2011, accepted March 252013

\begin{abstract}
This paper presents an overview of fifty-one articles from the Journal of Competitive Intelligence and Management (JCIM) posted on the Strategic and Competitive Intelligence Professionals' webpage. It also looks at sixty-tree randomly selected articles out of about 250 from the Competitive Intelligence Review (CIR), published between 1996 and 2001. The first analysis is based on a comparison with eleven different variables that have been picked out from each of the articles. Findings: The most common country where the authors' come from is the United States of America. Sixty-one of the eighty-three authors have a higher degree, first of all MBA and/or Ph.D. North American authors have a higher degree than authors from Europe. Authors from North America have contributed with fifty-seven percent of the proposals for further research of a total of twenty-one proposals. Fourteen articles have a professional author. The rest are academic contributions. The main topic in these articles is how to develop Competitive Intelligence (CI) but also how to define CI. The articles have different methodological approaches, qualitative and quantitative. Seventy tree percent have a qualitative approach and of those there are thirty-seven percent that also have a qualitative approach. For the second analysis dedicated to CIR one clear conclusion points to the large number of articles which resulted from the introduction of the Economic Espionage Act of 1997. Most contributions at CIR come from practitioners. ${ }^{1}$
\end{abstract}

KEYWORDS: Journal of Competitive Intelligence and Management, Competitive Intelligence Review, historical method, review

\footnotetext{
1 Thanks to Lovisa Andreasson, Isabell Bergsten, Johanna Ossiansson, Fredrik Garnäs, Erik Hagberg and Niklas Radhammar for help with this article.
} 


\section{Introduction}

\subsection{The aim of this paper}

The purpose of this study is to present an overview of scientific articles in the Journal of Competitive Intelligence and Management (JCIM) and the Competitive Intelligence Review (CIR). The analyses were done to bring clarity on key variables identified for this study. Part $1.2-3$ are concerned with JCIM. Part 4 is concerned with CIR.

\subsection{Focus}

The first table (table 1.) show empirical findings divided into eleven variables. These variables form the basis of the analysis. These are; geographic, focus, theoretical, empirical, qualitative, quantitative, proposals for further research, the author's background, gender, nationality and education. Geographic means were the study takes place and were the research is done, focus is the authors main topic in the article, theoretical empirical/ qualitativel quantitative these are variables that show how the articles are built-up and which method have been used. Proposals for further research are suggestions for continued research. Author's background tells us if the author works at a university or for a company. Gender is the sex of the author(s). Nationality tells us where the authors are citizens and Education is the author's degrees.

\subsection{Report structure}

The report is structured as follows: Section 2 is Methodology. In Section 3 Empirical findings are

\section{Empirical findings}

Data is provided for fifty-one articles. Thirty-three percent are about CI as a new study and its represented. This includes a table of all the scientific articles that have been investigated. Other tables and diagrams can be found here, containing comparisons with selected variables. Conclusions from the empirical findings are placed in this section. Section 4 contains an overview of article published in CIR. Conclusions which summarizes the papers findings are found in section 5, followed by references of all articles checked.

\section{Methodology}

The Journal of Competitive Intelligence and Management was published between 2004 and 2008. Three articles were excluded from this overview as they did not include a sufficient amount of variables.

An empirical analysis was conducted in order to detect similarities and inequalities in the articles. To compare the articles, eleven variables were selected. The selected variables were picked out from reading a few articles at random first. Similar variables were interesting to explore further in other articles. The empirical table is focused on eleven variables. These variables form the basis of the analysis and conclusions.

There are three tables. Table 1 shows Geographical background, focus of research articles and it says whether or not the article is theoretical or empirical. Table 2 continues and says whether articles are qualitative or quantitative and what suggestions they have for future research. Table 3 shows authors professional background, Gender, nationality and education level.

different forms in different countries. This reflects the newness of the topic.

\begin{tabular}{lllll}
\hline Art & Geographic & Focus & Theo & Emp \\
\hline 1 & Italy & Customer satisfaction & $\mathrm{X}$ & $\mathrm{X}$ \\
\hline 2 & Finland & Business information & $\mathrm{X}$ & \\
\hline 3 & Canada & Technology & & $\mathrm{X}$ \\
\hline 4 & Brasilia & Relation: BI and business success & $\mathrm{X}$ & $\mathrm{X}$ \\
\hline 5 & New Zealand & Development of CI & $\mathrm{X}$ & $\mathrm{X}$ \\
\hline 6 & Lithuania & Development of CI & $\mathrm{X}$ & $\mathrm{X}$ \\
\hline 7 & Japan & Current status of CI in Japanese business & & $\mathrm{X}$ \\
\hline 8 & Germany & CI in Germany & $\mathrm{X}$ & \\
\hline 9 & UK & Software & $\mathrm{X}$ & \\
\hline 10 & Canada, US, UK, & CI status on the web & & $\mathrm{X}$ \\
11 & Uapan, China & Competitive advantage & $\mathrm{X}$ & \\
\hline 12 & US & Marketing & & $\mathrm{X}$ \\
\hline
\end{tabular}




\begin{tabular}{|c|c|c|c|c|}
\hline 13 & US & $\mathrm{BI}$ & $\mathrm{X}$ & \\
\hline 14 & US & Knowledge management/ Value chain & $\mathrm{X}$ & \\
\hline 15 & US & CI field study & $\mathrm{X}$ & \\
\hline 16 & Greece & Corporate Intelligence & $\mathrm{X}$ & \\
\hline 17 & Australia, US & $\begin{array}{l}\text { Managing and compering in competitive } \\
\text { Intelligence in Australia versus USA }\end{array}$ & $\mathrm{X}$ & \\
\hline 18 & Korea & $\begin{array}{l}\text { How CI developed in Korea, focus on } \\
\text { environment }\end{array}$ & $\mathrm{X}$ & \\
\hline 19 & Russia & How CI developed in Russia & $\mathrm{X}$ & $\mathrm{X}$ \\
\hline 20 & Spain & How CI developed in Spain, barriers. & $\mathrm{X}$ & $\mathrm{X}$ \\
\hline 21 & Sweden & How CI developed in Sweden & $\mathrm{X}$ & \\
\hline 22 & Canada & $\begin{array}{l}\text { How CI developed in Canada, problems with } \\
\text { pessimism, unawareness }\end{array}$ & $\mathrm{X}$ & \\
\hline 23 & Finland & How CI developed in Finland & $\mathrm{X}$ & $\mathrm{X}$ \\
\hline 24 & Israel & $\begin{array}{l}\text { How CI developed in Israel, preparing for } \\
\text { threats }\end{array}$ & $\mathrm{X}$ & $\mathrm{X}$ \\
\hline 25 & South Africa & How CI developed in South Africa & $\mathrm{X}$ & $\mathrm{X}$ \\
\hline 26 & UK & How CI developed in UK, notoriety. & $\mathrm{X}$ & $\mathrm{X}$ \\
\hline 27 & Canada & How should you act In terror crises in BI & $\mathrm{X}$ & \\
\hline 28 & US & Understand the rolls in Informal Networks & $\mathrm{X}$ & $\mathrm{X}$ \\
\hline 29 & Spain & How to get $\mathrm{CI}$ in ethical ways & $\mathrm{X}$ & \\
\hline 30 & US & How to divide in virtual team & $\mathrm{X}$ & \\
\hline 31 & US & $\begin{array}{l}\text { How to collect and convert knowledge into } \\
\text { an advantage }\end{array}$ & $\mathrm{X}$ & \\
\hline 32 & France & $\begin{array}{l}\text { Find creative ways to gather intelligence in } \\
\text { org. Environment }\end{array}$ & $\mathrm{X}$ & \\
\hline 33 & Israel & $\begin{array}{l}\text { How different concept taken from the field of } \\
\text { topics can tribute to BI }\end{array}$ & $\mathrm{X}$ & \\
\hline 34 & US & Defining CI & $\mathrm{X}$ & \\
\hline 35 & US & Accounting as $\mathrm{CI}$ & $\mathrm{X}$ & $\mathrm{X}$ \\
\hline 36 & Finland & $\begin{array}{l}\text { Implications that CI operations have on Co- } \\
\text { evolution }\end{array}$ & $\mathrm{X}$ & \\
\hline 37 & France & $\begin{array}{l}\text { The emergence and uniqueness of CI in } \\
\text { France }\end{array}$ & $\mathrm{X}$ & \\
\hline 38 & US and Canada & Critical factors to assess CI performance & $\mathrm{X}$ & $\mathrm{X}$ \\
\hline 39 & UK & Increasing global demand for BI & $\mathrm{X}$ & \\
\hline 40 & US & Examination of the classic CI model & $\mathrm{X}$ & \\
\hline 41 & US & $\begin{array}{l}\text { Process oriented view of CI and it's impact on } \\
\text { organizational performance }\end{array}$ & $\mathrm{X}$ & $\mathrm{X}$ \\
\hline 42 & UK, Canada, US & $\begin{array}{l}\text { Bibliography and Assessment of Key } \\
\text { Competitive Intelligence Scholarship }\end{array}$ & $\mathrm{X}$ & \\
\hline 43 & US & $\begin{array}{l}\text { Existence and Usage of CI in Professional } \\
\text { Sports }\end{array}$ & $\mathrm{X}$ & $\mathrm{X}$ \\
\hline 44 & US & $\begin{array}{l}\text { Using CI processes to create value in the } \\
\text { healthcare industry }\end{array}$ & $\mathrm{X}$ & $\mathrm{X}$ \\
\hline 45 & Finland & $\begin{array}{l}\text { Analysis of the intelligence activities of } \\
\text { Finnish companies }\end{array}$ & $\mathrm{X}$ & $\mathrm{X}$ \\
\hline 46 & Canada & $\begin{array}{l}\text { Reporting on the State of the Art (Scip06 } \\
\text { academic program) }\end{array}$ & $\mathrm{X}$ & \\
\hline 47 & 2 UK 1 Lebanon & $\begin{array}{l}\text { The Contribution of CI to the Strategic Decision } \\
\text { Process }\end{array}$ & Making & $\mathrm{X}$ \\
\hline 48 & US and Canada & Improve awareness of environmental scanning $\mathrm{p}$ & ractices & $\mathrm{X}$ \\
\hline 49 & $\begin{array}{l}\text { UK, Rome, Mongolia, } \\
\text { Japan, China, Middle }\end{array}$ & $\begin{array}{l}\text { Tracing the Origins of Competitive } \\
\text { Intelligence }\end{array}$ & $\mathrm{X}$ & \\
\hline
\end{tabular}




\begin{tabular}{llll} 
& east, US & \\
50 & Canada & $\begin{array}{l}\text { To provides a practical teaching tool for } \\
\text { business educators }\end{array}$ & $\mathrm{X}$ \\
51 & US & Info-Terrorism in the Age of the Internet & $\mathrm{X}$ \\
\hline
\end{tabular}

\begin{tabular}{|c|c|c|c|}
\hline Art & Qualitative & Quantitative & Proposals for further research (when applic.) \\
\hline 1 & $\mathrm{X}$ & & \\
\hline 2 & $\mathrm{X}$ & & Test the cube \\
\hline 3 & $\mathrm{X}$ & & Value of technology \\
\hline 4 & $X$ & $\mathrm{X}$ & \\
\hline 5 & $\mathrm{X}$ & & Courses in CI \\
\hline 6 & & $\mathrm{X}$ & \\
\hline 7 & & $\mathrm{X}$ & \\
\hline 8 & $\mathrm{X}$ & & \\
\hline 9 & $X$ & & Field study of software to identify CI-technics \\
\hline 10 & & $\mathrm{X}$ & The value of webometrics \\
\hline 11 & $\mathrm{X}$ & & CI's effect on businesses \\
\hline 12 & $\mathrm{X}$ & & Memetics and psychological factors \\
\hline 13 & $\mathrm{X}$ & & \\
\hline 14 & $X$ & & \\
\hline 15 & $\mathrm{X}$ & & Field study of CI \\
\hline 16 & $\mathrm{X}$ & & \\
\hline 17 & $X$ & $\mathrm{X}$ & Australia should take lessons from the U.S. \\
\hline 18 & $\mathrm{X}$ & $\mathrm{X}$ & $\begin{array}{l}\text { Check the cultural background to get the } \\
\text { foundation of the theory }\end{array}$ \\
\hline 19 & $\mathrm{X}$ & $\mathrm{X}$ & \\
\hline 20 & $\mathrm{X}$ & $\mathrm{X}$ & \\
\hline 21 & $X$ & & Research to be the leader of the CI in the EU \\
\hline 22 & $\mathrm{X}$ & & Raise awareness of CI in Canada \\
\hline 23 & $\mathrm{X}$ & & \\
\hline 24 & $\mathrm{X}$ & & \\
\hline 25 & & $\mathrm{X}$ & \\
\hline 26 & & $\mathrm{X}$ & \\
\hline 27 & & $\mathrm{X}$ & \\
\hline 28 & $\mathrm{X}$ & & $\begin{array}{l}\text { Study informal roles highlighted in the literature, } \\
\text { affect IM }\end{array}$ \\
\hline 29 & & $\mathrm{X}$ & \\
\hline 30 & & $\mathrm{X}$ & \\
\hline 31 & & $\mathrm{X}$ & \\
\hline 32 & $\mathrm{X}$ & & \\
\hline 33 & $X$ & & \\
\hline 34 & $\mathrm{X}$ & & Continued research about defining CI \\
\hline 35 & $X$ & $X$ & $\begin{array}{l}\text { Include members from SCIP outside the US. and } \\
\text { Canada. The use of CI may be tied to another } \\
\text { management innovation. }\end{array}$ \\
\hline 36 & $X$ & & $\begin{array}{l}\text { Empirical study about the effects of adopting CI } \\
\text { solutions and processes }\end{array}$ \\
\hline 37 & $\mathrm{X}$ & & \\
\hline
\end{tabular}




\begin{tabular}{|c|c|c|c|}
\hline 38 & $X$ & & \\
\hline 39 & $X$ & & \\
\hline 40 & $X$ & & \\
\hline 41 & $X$ & $X$ & $\begin{array}{l}\text { Examine how different types of analysis are } \\
\text { related to patterns of dissemination. }\end{array}$ \\
\hline 42 & $X$ & & \\
\hline 43 & & $X$ & $\begin{array}{l}\text { Analyze the relationship between the performance } \\
\text { of the organization and the use of various CI } \\
\text { activities and to seek the link between CI and } \\
\text { strategic planning. }\end{array}$ \\
\hline 44 & $X$ & & $\begin{array}{l}\text { A quantitative study using a survey instrument to } \\
\text { explore the relationship between the use of formal } \\
\text { HR related CI processes and measures of strategic } \\
\text { and HR performance. }\end{array}$ \\
\hline 45 & $X$ & & \\
\hline 46 & $X$ & & \\
\hline 47 & $X$ & $X$ & $\begin{array}{l}\text { Investigation into the physiology of effective CI } \\
\text { managers in a high technology/innovation driven } \\
\text { industry. }\end{array}$ \\
\hline 48 & $X$ & & \\
\hline 49 & $X$ & & $\begin{array}{l}\text { how some countries have managed to position } \\
\text { themselves as economically stronger then their } \\
\text { neighbors, and how intelligence has played a part in } \\
\text { their growth. }\end{array}$ \\
\hline 50 & $X$ & & \\
\hline 51 & $X$ & & \\
\hline
\end{tabular}

Table 2: Method and suggestions for future research (when applicable)

\begin{tabular}{|c|c|c|c|c|}
\hline Art & The authors' background & Gender & Nationality & Education \\
\hline 1 & University & Female & Italian & Ph.D. \\
\hline 2 & University & Female, Male & Finland & Dr., MSc. \\
\hline 3 & University & Male & US & Ph.D. \\
\hline 4 & University & Male & Brasilia & Dr. \\
\hline 5 & University & Male & New Zeeland & None \\
\hline 6 & University & $\begin{array}{l}1 \text { Female, } 2 \\
\text { Males }\end{array}$ & Lithuania & $\begin{array}{l}\text { MBA \& Ph.D., } \\
\text { None, None }\end{array}$ \\
\hline 7 & University & Male & Japan & MBA \\
\hline 8 & University & Male & Germany & MBA \\
\hline 9 & University & Female Male & UK & $\begin{array}{l}\text { None, Ph.D. \& } \\
\text { CISA }\end{array}$ \\
\hline 10 & University & Female, Male & Canada & None, MLIS \\
\hline 11 & University & Female & US & $\begin{array}{l}\text { BS \& MBA \& } \\
\text { Ph.D. }\end{array}$ \\
\hline 12 & University & Male & US & BD\&MBA \\
\hline 13 & University & Female & US & Ph.D., MB \\
\hline 14 & University & Female, Male & US & $\begin{array}{l}\text { Ph.D. \& MBA \& } \\
\text { BA, Ph.D. \& MBA } \\
\& \text { BS }\end{array}$ \\
\hline 15 & University & $\begin{array}{l}1 \text { Female, } 2 \\
\text { Males }\end{array}$ & US & Ph.D., Ph.D., Ph.D. \\
\hline 16 & Business & Male & Greece & Ph.D. \\
\hline 17 & Business, University & Female, Male & Australia & None, BSc. \\
\hline
\end{tabular}




\begin{tabular}{|c|c|c|c|c|}
\hline 18 & University & 2 Males & Korea, France & Ph.D., None \\
\hline 19 & Business & Male & Russia & None \\
\hline 20 & University & 2 Males & Spain & $\begin{array}{l}\text { Ph.D. \& Ph.D. \& } \\
\text { MBA, BSc. \& MBA }\end{array}$ \\
\hline 21 & Business & Male & Sweden & None \\
\hline 22 & University & 2 Males & Canada & None, none \\
\hline 23 & Business & Female & Finland & None, none \\
\hline 24 & Business & Male & Israel & None \\
\hline 25 & University, Business & Female & South Africa & Ph.D. \& BEd, None \\
\hline 26 & University & $\begin{array}{l}1 \text { Female, } 3 \\
\text { Males }\end{array}$ & UK & $\begin{array}{l}\text { MBA, BSc, } \\
\& \text { MSc.\& Dr., None, } \\
\text { None }\end{array}$ \\
\hline 27 & University & Male & Canada & None \\
\hline 28 & Business \& University & Female & US & MBA\&MA \\
\hline 29 & University \& Business & Male & Spain & BSc. \& MBA \\
\hline 30 & $\begin{array}{l}\text { Business, Business \& } \\
\text { University }\end{array}$ & Female, Male & Qatar, US & BD\&MBA \\
\hline 31 & Business \& University & Female & US & $\begin{array}{l}\text { Ph.D \& MA \& } \\
\text { MBA }\end{array}$ \\
\hline 32 & University & $\begin{array}{l}2 \text { Females, } 1 \\
\text { Male }\end{array}$ & France & Ph.D., None, Ph.D. \\
\hline 33 & University \& Business & Male & Israel & $\begin{array}{l}\text { MBA \& MSc. \& } \\
\text { B.Sc. }\end{array}$ \\
\hline 34 & University & Female & US & Ph.D. \\
\hline 35 & University & Male & US & MBA \& Ph.D \\
\hline 36 & University & 2 Females & Finland & M.Sc., M.Sc. \\
\hline 37 & University & Male, Female & France & MBA, Ph.D. \\
\hline 38 & University & 2 Males & Canada & $\begin{array}{l}\text { None, BSBA \& } \\
\text { MBA \& Ph.D. }\end{array}$ \\
\hline 39 & University & Male & UK & Ph.D. \\
\hline 40 & Business & Male & US & $\begin{array}{l}\text { B.A\&J.D\&LL.M\& } \\
\text { M.A }\end{array}$ \\
\hline 41 & University & 2 Males & US & $\begin{array}{l}\text { B.Com \& MSc. \& } \\
\text { Ph.D., Ph.D., Ph.D. }\end{array}$ \\
\hline 42 & University & $\begin{array}{l}2 \text { Males } 1 \\
\text { Female }\end{array}$ & $\begin{array}{l}2 \text { Canada } 1 \\
\text { UK }\end{array}$ & $\begin{array}{l}\text { BSBA \& Ph.D., } \\
\text { MBA, B.Com }\end{array}$ \\
\hline 43 & University & Female, Male & US & $\begin{array}{l}\text { BS \& MBA \& } \\
\text { Ph.D., Ph.D. }\end{array}$ \\
\hline 44 & University & $\begin{array}{l}2 \text { Females } 1 \\
\text { Male }\end{array}$ & US & Ph.D., Ph.D., M.D. \\
\hline 45 & University & Female & Finland & MSc. \\
\hline 46 & University & Male & Canada & None \\
\hline 47 & University & $\begin{array}{l}2 \text { Females } 1 \\
\text { Male }\end{array}$ & UK & M.B, MBA \\
\hline 48 & University & Male & Canada & DBA \\
\hline 49 & University & 2 Males & UK & $\begin{array}{l}\text { BSc. \& MSc. \& } \\
\text { Ph.D., Ph.D. }\end{array}$ \\
\hline 50 & Business & Male & Canada & MBA \\
\hline 51 & University & Female & India & $\begin{array}{l}\text { Ph.D. \& MA \& } \\
\text { MBA }\end{array}$ \\
\hline
\end{tabular}

Table 3: Background, Gender, Nationality and Degrees 
The chart over the fifty-one articles shows that there are a total of eighty-three authors. That gives 1.63 writers per article.

Figure 1: JCIM Authors by country

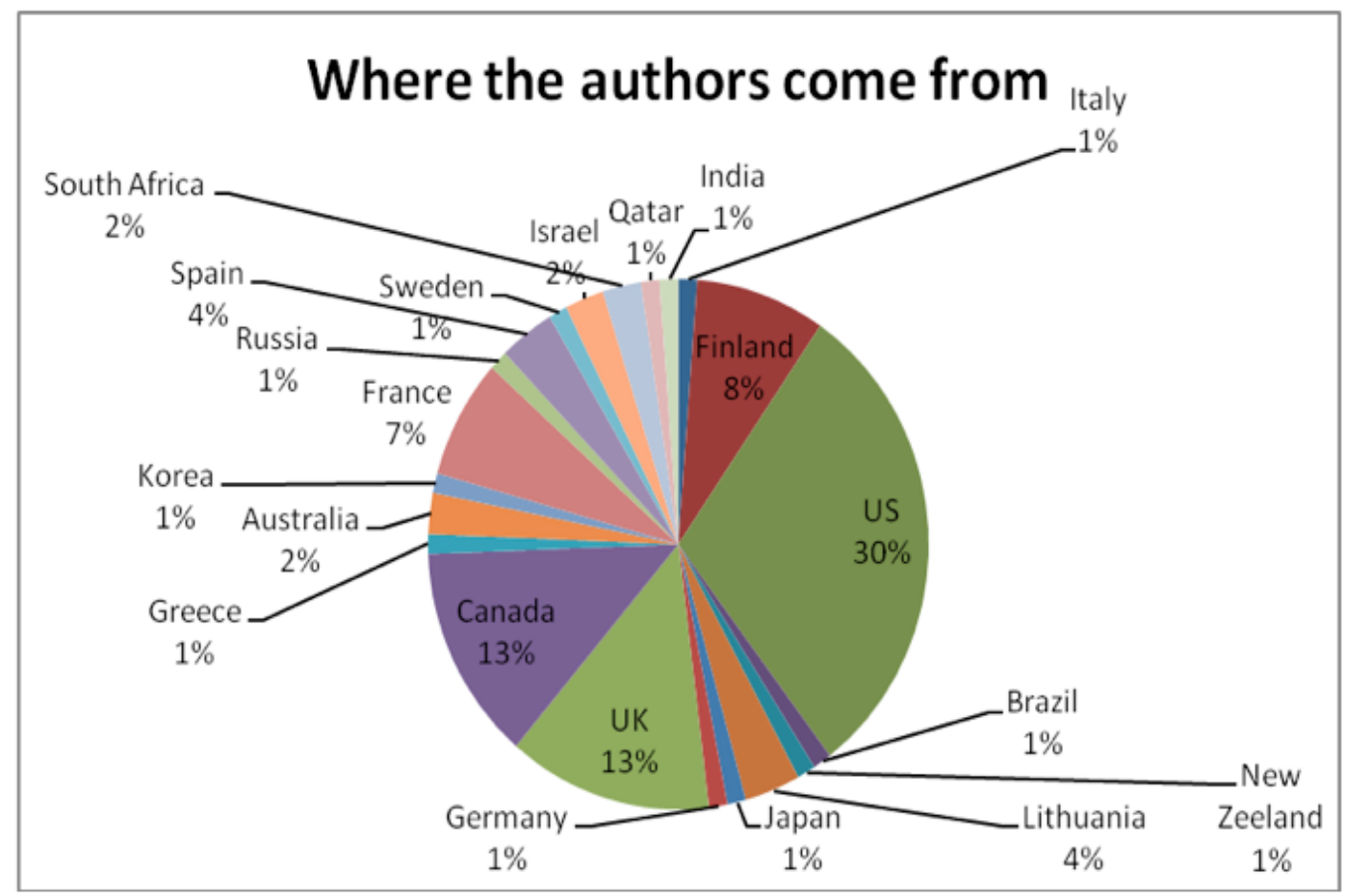

The chart shows that the authors comes from twenty-one different coutries, and the country most authors come from is the U.S with $30 \%$ of the writers. The countries that follow are Canada and the United Kingdom, both with $13 \%$ of the writers. The countries that are the least represented in the Journal of Competitive Intelligence and Management of the ones published is Brazil, Germany, Greece, India, Italy, Korea, Lithuania, New Zeeland, Russia,
Sweden and Qatar; all with $1 \%$ of the authors.

The authors' backgrounds show that $60 \%$ are males and $40 \%$ females. (Both editors were females.) Totally there were fifty men and thirty-three women represented as authors.

The table shows that sixty-one of these eighty-three authors have a higher academic degree, first of all MBA, Ph.D. and Dr.

\begin{tabular}{|l|c|c|c|c|c|l|}
\hline Continent & Ph.D. & Dr. & MBA & Other & None & $=$ \\
\hline Europe & 11 & 2 & 6 & 6 & 11 & $\mathbf{3 6}$ \\
\hline N. America & 19 & & 5 & 5 & 6 & $\mathbf{3 5}$ \\
\hline S. America & & 1 & & & & $\mathbf{1}$ \\
\hline Oceania & & & & 1 & 2 & $\mathbf{3}$ \\
\hline Asia & 2 & & 2 & 1 & 1 & $\mathbf{6}$ \\
\hline Africa & 1 & & & & 1 & $\mathbf{2}$ \\
\hline Tot. & $\mathbf{3 3}$ & $\mathbf{3}$ & $\mathbf{1 3}$ & $\mathbf{1 3}$ & $\mathbf{2 1}$ & $\mathbf{8 3}$ \\
\hline
\end{tabular}

Table 4: A summarized table of education and geographical location of authors 
Europe is represented with a total of thirty-six authors. Eleven of these have a PhDs degree, two have a Dr. degree (often equivalent to a $\mathrm{PhD}$, for example can be that the dissertation was completed in a German speaking country), six have an MBA degree, six have other sorts of higher degrees and eleven authors have no higher degree stated. North America is represented with nineteen $\mathrm{PhDs}$ degrees, no Dr., five MBAs, five other sorts of higher degree, six of no higher degree from a total of thirty-five authors in North America. South America has one Dr. degree represented. Oceania has one other sort of higher degree and two with no other higher degree. The continent of Asia has two PhDs, two MBAs, one other higher degree and one no higher degree. This makes a total of six authors from Asia. Africa got one $\mathrm{PhD}$ and one other no higher degree presented.
There are sixty-two authors who has got some form of degree, $47 \%$ of these are from North America. Europe comes next with $37 \%$ and the other four continents constitute under $10 \%$. On the PhD level North America is represented with the most, with $58 \%$ and Europe comes second with $33 \%$. The table demonstrates that the continent of North America is represented with higher degrees and more degrees then the continent of Europe despite that Europe got one more author represented than North America.

Table 1 shows that almost $40 \%$ of the articles suggest further research within the subject of Competitive Intelligence or Business Intelligence. There is a need identified to explore the areas deeper.

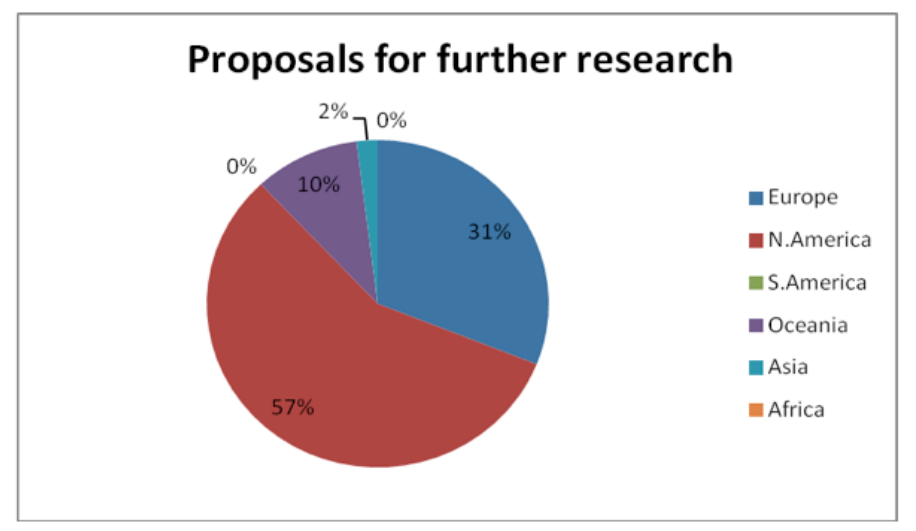

Figure 2: Articles with suggestions of future research

The chart above shows that the continent of North America gives $57 \%$ of all the proposals or suggestions for further research of a total of twenty-one proposals. Next come Europe with $31 \%$. Oceania has $10 \%$ of the proposals and Asia $2 \%$. South America and Africa are not represented with further proposals for future research.

Another variable that can have an impact on the articles is the author's backgrounds. Some authors are professionals, from the business community, but most come from universities and have an academic background. Out of fifty-one articles only fourteen have authors with a business community attachment. That is $27 \%$ of all articles published in JCIM.

A conclusion from the variable focus is that they can be divided in to different groups. The main topic is how to develop Competitive Intelligence but also how to define CI. The articles about developing CI have also different subjects. Some are about development in general (universal) others about development in different countries (cultural). The second largest group is on defining CI and about the growth of CI throughout history. The third largest focus is on Business Intelligence (BI) and how to use it in the best way.

Of all the articles about the use and development of CI, 90,9\% have chosen a qualitative approach and of those there are $30 \%$ that have both approaches. 9,10\% of all articles have chosen a quantitative approach. $100 \%$ of the articles with the topic defining CI are qualitative.

$100 \%$ of the articles on the topic of BI are qualitative, out of those $17 \%$ are both qualitative and quantitative. Out of those articles which explore CI in different industries $66,67 \%$ are qualitative, and $50 \%$ of those have both a qualitative and a quantitative approach. There are $33,33 \%$ which only use the quantitative approach. The articles that use only a qualitative approach typically have proposals for further research where they suggest a quantitative rmethod.

In total, of all articles regardless topic, there are $92,16 \%$ with a qualitative approach and of those 
there are $17,02 \%$ with both approaches. Only $7,84 \%$ has solely a quantitative approach.

\section{Overview of CIR}

When gathering information for the data set, we used a stratified random sample approach. The methodology gives the possibility to collect a number of articles from each year. From approximately 250 articles published between 1996 and 2001, we picked every fourth article to summarize in the data set. In the data set, we present the variables we found interesting for the summary. We used four levels of Competitive Intelligence as sub-categories. These were categories that were most popular as subjects: article about companies, products, about marketing and partnership and cooperation (organization). The sub-categories give the opportunity to analyze differences between articles on the four levels.

\subsection{Company level.}

The first category is the company level. These accounted for forty-seven articles.

\begin{tabular}{|c|c|c|}
\hline Origin & Quantity & Percentage \\
\hline USA & 31 & $65,96 \%$ \\
\hline Australia & 4 & $8,51 \%$ \\
\hline Canada & 2 & $4,26 \%$ \\
\hline Switzerland & 1 & $2,13 \%$ \\
\hline Italy & 1 & $2,13 \%$ \\
\hline Croatia & 2 & $4,26 \%$ \\
\hline Sweden & 2 & $4,26 \%$ \\
\hline Brazil & 2 & $4,26 \%$ \\
\hline Cuba & 1 & $2,13 \%$ \\
\hline Singapore & 1 & $2,13 \%$ \\
\hline & 47 & $100,00 \%$ \\
\hline Sex & Quantity & Percentage \\
\hline Male Male & 40 & $85,11 \%$ \\
\hline Female & 7 & $14,89 \%$ \\
\hline & 47 & $100,00 \%$ \\
\hline Based on & Quantity & Percentage \\
\hline Own experiences & 29 & $61,70 \%$ \\
\hline Case study & 11 & $23,40 \%$ \\
\hline Survey & 7 & $14,89 \%$ \\
\hline & 47 & $100,00 \%$ \\
\hline Authors background & Quantity & Percentage \\
\hline Industry & 28 & $\mathbf{5 9 , 5 7 \%}$ \\
\hline Academic & 19 & $40,43 \%$ \\
\hline & 47 & $100,00 \%$ \\
\hline Method or Purpose & Quantity & Percentage \\
\hline Quantitative & 6 & $12,77 \%$ \\
\hline Qualitative & 2 & $4,26 \%$ \\
\hline Informative & 18 & $38,30 \%$ \\
\hline Guide-to & 21 & $44,68 \%$ \\
\hline & 47 & $100,00 \%$ \\
\hline
\end{tabular}


4.2 Product level

is used to support product development.

The table below gives a summary of the The second category is articles about products, where CI findings:

\begin{tabular}{|lr|r|}
\hline Origin & Quantity & Percentage \\
USA & 4 & $\mathbf{8 0 , 0 0 \%}$ \\
\hline & 1 & $20,00 \%$ \\
\hline Sex & 5 & $100,00 \%$ \\
Male & Quantity & Percentage \\
Female & 4 & $\mathbf{8 0 , 0 0 \%}$ \\
\hline & 1 & $20,00 \%$ \\
\hline Based on & 5 & $100,00 \%$ \\
Own experiences & Quantity & Percentage \\
Case study & 4 & $\mathbf{8 0 , 0 0 \%}$ \\
Survey & 1 & $20,00 \%$ \\
\hline & 0 & $0,00 \%$ \\
\hline Authors background & Quantity & Percentage \\
Industrial & 4 & $\mathbf{8 0 , 0 0 \%}$ \\
Academic & 1 & $20,00 \%$ \\
\hline & 5 & $100,00 \%$ \\
\hline Method or Purpose & Quantity & Percentage \\
Quantitative & 0 & $0,00 \%$ \\
Qualitative & 0 & $0,00 \%$ \\
Informative & 3 & $\mathbf{6 0 , 0 0 \%}$ \\
Guide-to & 2 & $40,00 \%$ \\
\hline & 5 & $100,00 \%$ \\
\hline
\end{tabular}

Table 6: Articles categorized by the Product level

\subsection{Marketing level}

Articles about Marketing is the third category. It contains all data from the articles that treats marketing as a function in connection with $\mathrm{CI}$.

\begin{tabular}{|lr|c|}
\hline Origin & Quantity & Percentage \\
USA & 5 & $\mathbf{8 3 , 3 3 \%}$ \\
Great Britain & 1 & $16,67 \%$ \\
\hline & 6 & $100,00 \%$ \\
\hline Sex & Quantity & Percentage \\
Male & 4 & $\mathbf{6 6 , 6 7 \%}$ \\
Female & 2 & $33,33 \%$ \\
\hline & 6 & $100,00 \%$ \\
\hline Based on & Quantity & Percentage \\
Own experiences & 6 & $\mathbf{1 0 0 , 0 0 \%}$ \\
Case study & 0 & $0,00 \%$ \\
Survey & 0 & $0,00 \%$ \\
\hline & 6 & $100,00 \%$ \\
\hline Authors background & Quantity & Percentage \\
Industrial & 4 & $\mathbf{6 6 , 6 7 \%}$
\end{tabular}




\begin{tabular}{|lr|c|}
\hline Academic & 2 & $33,33 \%$ \\
\hline Method or Purpose & 6 & $100,00 \%$ \\
Quantitative & 0 & $0,00 \%$ \\
Qualitative & 0 & $0,00 \%$ \\
Inform & 4 & $\mathbf{6 6 , 6 7 \%}$ \\
Guide & 2 & $33,33 \%$ \\
\hline & 6 & $100,00 \%$ \\
\hline
\end{tabular}

Table 7: Articles categorized by the Marketing level

\subsection{Partnership level}

The last category is called partnership level. We placed here all data from articles that are about the cooperation between different companies and different departments within a company as relates to CI.

\begin{tabular}{|c|c|c|}
\hline Origin & Quantity & Percentage \\
\hline USA & 1 & $25,00 \%$ \\
\hline Great Britain & 1 & $25,00 \%$ \\
\hline Canada & 1 & $25,00 \%$ \\
\hline Hungary & 1 & $25,00 \%$ \\
\hline & 4 & $100,00 \%$ \\
\hline Sex & Quantity & Percentage \\
\hline Male & 1 & $25,00 \%$ \\
\hline Female & 3 & $75,00 \%$ \\
\hline & 4 & $100,00 \%$ \\
\hline Based on & Quantity & Percentage \\
\hline Own experiences & 1 & $25,00 \%$ \\
\hline Case study & 2 & $50,00 \%$ \\
\hline Survey & 1 & $25,00 \%$ \\
\hline & 4 & $100,00 \%$ \\
\hline Authors background & Quantity & Percentage \\
\hline Industrial & 3 & $75,00 \%$ \\
\hline Academic & 1 & $25,00 \%$ \\
\hline & 4 & $100,00 \%$ \\
\hline Method or Purpose & Quantity & Percentage \\
\hline Quantitative & 0 & $0,00 \%$ \\
\hline Qualitative & 1 & $25,00 \%$ \\
\hline Inform & 3 & $75,00 \%$ \\
\hline Guide & 0 & $0,00 \%$ \\
\hline & 4 & $100,00 \%$ \\
\hline
\end{tabular}

\section{Conclusion}

In conclusion CIR was a popular magazine primarily for the American market. This is reflected in the high number of American authors (67\%) writing about their experience with $\mathrm{CI}$ in different companies. 85\% of contributions were made by men and $60 \%$ by practitioners in the first group. The trend is even stronger in the second group, with articles about products. It is about the same in the group on marketing too, but here female participants are more numerous. In the last group females are in the majority $(75 \%)$. There is also a much more even distribution between countries of origin. Very few articles have a clear quantitative or qualitative approach, but are most informative and explorative in nature. 


\section{References for JCIM}

Antia, D. K., \& Hesford, W. J. 2007. A Process Oriented View of Competitive Intelligence and its Impact on Organizational Performance. Journal of Competitive intelligence and management 4(1), 3-31.

Awazu, Y. 2005. "Informal Roles and Intelligence Activities: Some Management Propositions, Journal of Competitive Intelligence and Management 2(1): 16-24.

Badr, A., Pickton, A., Weiss, A., and Wright, S. 2005. Competitive Intelligence through UK Eyes. Journal of Competitive Intelligence and Management 2(2): 68-87.

Badr, A., Madden, E., and Wright, S. 2006. The Contribution of CI to the Strategic Decision Making Process: Empirical Study of the European Pharmaceutical Industry. Journal of Competitive intelligence and management 3(4): 15-35.

Belkin, M. 2005.Competitive Intelligence in Israel, Journal of Competitive Intelligence and Management 2(2): 38-52.

Bensoussan, B., and Densham, D. 2005. Australian CI Practices: A Comparison with the U.S. Journal of Competitive Intelligence and Management 2(3):01-09.

Blanco, S., Caron-Fasan, M-L., and Lesca, H. 2004. Developing Capabilities to Create Collective Intelligence Within Organizations. Journal of Competitive Intelligence and Management 1(1): 80-92.

Blenkhorn, L. D., \& Fleisher, S. C. 2007. Performance Assessment in Competitive Intelligence: An Exploration, Synthesis, and Research Agenda. Journal of Competitive intelligence and management 4(2), 4-22.

Bouthillier, F., and Jin, T. 2005. CI Professionals and their Interactions with CI Technology: A Research Agenda. Journal of Competitive Marketing Intelligence and Management 3(1): 41-53.

Bouthillier, F., and Jin T. 2005. Competitive Intelligence and Webometrics: An Exploratory Study on the Status of CI in Five Countries. Journal of Competitive Intelligence and Management 3(3): 19-39.

Brody, R. 2008. Issues in Defining Competitive Intelligence: An Exploration. Journal of Competitive intelligence and management 4(3), 3-16.

Brouard, F. 2006. Development of an Expert System on Environmental Scanning P

ractices in SME: Tools as a Research Program. Journal of Competitive intelligence and management 3(4), 37-55.

Brouard, F., 2005. Business Intelligence Canadian Corporations after September 11.
Journal of Competitive Intelligence and Management 2(1):01-15.

Brouard, F. and Calof, J., 2005. Competitive Intelligence in Canada. Journal of Competitive Intelligence and Management 2(2):01-21

Calof, J. 2006. The SCIP06 Academic Program - Reporting on the State of the Art. Journal of Marketing intelligence and management 3(4), 5-13.

Cobb, P., 2004. Competitive Intelligence Through Data Mining. Journal of Competitive Intelligence and Management 1(3): 80-89.

Comai, A., 2005.Global Code of Ethic and Competitive Intelligence Purposes: an Ethical Perspective on Competitors. Journal of Competitive Intelligence and Management 2(1): 25-44.

Comai, A. and Millán, T.J. 2005 Competitive Intelligence in Spain: a Situational Apprasial. Journal of Competitive Intelligence and Management 2(3): 45-55.

Dalla Pozza, I. 2005. Introducing a Marketing based Perspective in Alliance Formation. Journal of Competitive Intelligence and Management 3(1): 16-31.

Desouza, K.C. and Luthra, A. 2004.Intelligence Sharing in Virtual Teams: Managing Organizational Effects of Technology. Journal of Competitive Intelligence and Management 1(3):01-09.

Erickson S. G., and Rothberg N. H. 2006. Expanding Intelligence Capabilities: Downstream Knowledge Targets. Journal of Competitive Intelligence and Management, 3(2):08-15.

Fleisher, S. C., Tindale, R., and Wright, S. 2007. Bibliography and Assessment of Key Competitive Intelligence Scholarship: Part 4 (2003-2006). Journal of Competitive intelligence and management 4(1): 32-93.

Frates, J., and Sharp S. 2006. Using Business Intelligence to Discover New Market Opportunities, Journal of Competitive Intelligence and Management 3(2): 16-25.

Ganesh, U., Miree, E. C and Prescott J. 2003. Competitive Intelligence Field Research: Moving the Field Forward by Setting a Research Agenda. Journal of Competitive Intelligence and Management, 1(1): 01-12.

Hannula, M., and Pirtimaki, V. 2005. A cube of business information. Journal of Competitive Intelligence and Management 3(1): 34-40.

Hawkins, B. 2004. Competitive Intelligence in New Zealand. Journal of Competitive Intelligence and Management 2(4): 42-52.

Hedin, H. 2005. Evolution of Competitive Intelligence in Sweden. Journal of Competitive Intelligence and Management 
2(3): 56-75.

Herzog, O. J. 2007. Why Is There An Increasing Global Demand for Business Intelligence? Journal of Competitive intelligence and management 4(2): 55-70.

Hesford, W. J. 2008. An Empirical Investigation of Accounting Information Use in Competitive Intelligence. Journal of Competitive intelligence and management 4(3): 17-49.

Hirvensalo, I. 2005. Competitive Intelligence in Finland. Journal of Competitive Intelligence and Management 2(2): 22-37.

Hughes, S. 2005. Intelligence as Competitive Advantage. Journal of Competitive Intelligence and Management 3(3): 03-18.

Hughes, S., and Beasley, F. 2007. An Examination of the Existence and Usage of Competitive Intelligence in Professional Sports. Journal of Competitive intelligence and management 4(1): 93-111.

Http://competitiveintelligence.ning.com, Definition of CI, 2011-11-25

Ignatov, A. A. 2005. Competitive Intelligence in Russia. Journal of Competitive Intelligence and Management 2(3): 26-44.

Jucevicius, R., Oržekauskas, P., and Stankeviciute, P. 2004. Competitive Intelligence in Lithuania. Journal of Competitive Intelligence and Management 2(4): 32-41.

Juhari, S. A., and Stephens, D. 2006. Tracing the Origins of Competitive Intelligence Throughout History. Journal of Competitive intelligence and management 3(4): 61-82.

Kim, K., and Kim, S. 2005. Competitive Intelligence in Korea. Journal of Competitive Intelligence and Management 2(3): $10-25$

Knip, V. 2006. Culture Counts! Teaching Business Students Why and How to Leverage Cultural Analysis to Optimize Global Macro-Environmental Scanning. Journal of Competitive Marketing intelligence and management 3(4): 85-110.

Kossou, L., and Smith, J. 2008. The Emergence and Uniqueness of Competitive Intelligence in France. Journal of Competitive intelligence and management 4(3): 63-85.

Lombardo, V. S., Miree, E. C., and York, M. K. 2007. Using Competitive Intelligence Processes to Create Value in the Healthcare Industry. Journal of Competitive intelligence and management 4(1): 112-131.

McGonagle, J. J. 2007. An Examination of the 'Classic' CI Model. Journal of Competitive intelligence and management 4(2): 71-86.

Michaeli, R. 2004. Competitive Intelligence in Germany. Journal of Competitiv Intelligence and Management 2(4): 01-06.
Muller, M-L., and Viviers, W. (2005. The Evolution of Competitive Intelligence in South Africa: Early 1980s-2003. Journal of Competitive Intelligence and Management 2(2): 53-67.

Nakra, P. 2003. Info-Terrorism in the Age of the Internet: Challenges and Initiatives. Journal of Competitive intelligence and management 1(2): 1-10.

Neugarten, M. 2004. Seeing and Noticing: An Optical Perspective on Competitive Intelligence. Journal of Competitive Intelligence and Mangement 1(1): 93-104.

O'Gorman, D. 2006. Memes, CI and Marketing: A Preliminary Framework. Journal of Competitive Intelligence and Management 3(2): 29-43.

Peltoniemi, M., and Vuori, E. 2008. Competitive Intelligence as a Driver of Co Evolution within an Organization Population. Journal of Competitive intelligence and management 4(3): 50-62.

Persidis, A. 2003. Corporate Intelligence in a 'Corporately Intelligent' World. Journal of Competitive Intelligence and Management 1(2): 89-99.

Pirttimäki, V. 2007. Comparative Study and Analysis of the Intelligence Activities of Large Finnish Companies. Journal of Marketing intelligence and management 4(1): 132-155.

Pontes, C. E. 2005. The Relationship between Business Intelligence and Business Success. Journal of Competitive Intelligence and Management 3(1): 06-15.

\section{References for CIR}

Achard, P. 1996. The annual report: A legal document that you should read at regular intervals. Competitive Intelligence Review 7(1): 78-82.

Arnett, D. B., Menon, A., and Wilcox, J. B. Using competitive intelligence: Antecedents and consequences. Competitive Intelligence Review 11(3): 16-27.

Bannister, G. J., Muller, H. J., and Rehder, R. R. 1996. Ford-Mazda's hermosillo assembly plant: A quality benchmark cross-cultural alliance. Competitive Intelligence Review 7(2): 11-19.

Bauman, J. H., and Gelinne, M. 1998. Maximizing the use of CI consultants: A corporate practitioner's perspective. Competitive Intelligence Review 9(3): 3-8.

Bigwood, M. P. 1996. "Normalized" patent trend analysis: Eliminating the impact of nonrelevant variables. Competitive Intelligence Review 7(4): 37-45. 
Breeding, B. 2000. CI and KM convergence: A case study at Shell Services International. Competitive Intelligence Review 11(4): 1224.

Breitzman, A. F. 2000. Assessing an industry's R\&D focus rapidly: A case study using datadriven categorization in a consumer products area. Competitive Intelligence Review 11(1): 58-64.

Brenner, M. S. 1996. Technology intelligence and technology scouting. Competitive Intelligence Review 7(3): 20-27.

Burkhardt, K. E. 2001. Competitive intelligence and the product life cycle. Competitive Intelligence Review 12(3): 35-43.

Calof, J. 1999. Overcoming Competitive Intelligence barriers: A SCIP tool kit. Competitive Intelligence Review 10(1): 7178.

Calof, J. L. 1997. So you want to go international? What information do you need and where will you get it?. Competitive Intelligence Review 8(4): 19-29.

Chaves, H., Canongia, C., Gaspar, A., Maffia, S., de Nazaré, M., and Pereira, F. 2000. The potential of competitive intelligence tools for knowledge management: A study of a Brazilian database. Competitive Intelligence Review 11(4): 47-56.

Chussil, M. J. 1996. Competitive intelligence goes to war: CI, the war college, and competitive success. Competitive Intelligence Review 7(3): 56-69.

Collins, A., and Schultz, N. 1996 A review of ethics for competitive intelligence activities. Competitive Intelligence Review 7(2): 56-66.

Davison, L. 2001. Measuring competitive intelligence effectiveness: Insights from the advertising industry. Competitive Intelligence Review 12(4): 25-38.

Dedijer, S. 1998. Competitive intelligence in Sweden. Competitive Intelligence Review 9(1): 66-68.

Dedijer, S. 1999. Doing business in a changed world: The intelligence revolution and our planetary civilization. Competitive Intelligence Review 10(3): 67-78.

Doviak Brown, J., and Prescott, J. E. 2000. Products of the mind: Assessment and protection of intellectual property. Competitive Intelligence Review 11(3): 6076.

Fahey, L. 1999. Competitor scenarios: Projecting a rival's marketplace strategy. Competitive Intelligence Review 10(2): 65-85.

Fine, N. R. 1997. The economic espionage act: Turning fear into compliance. Competitive Intelligence Review 8(3): 20-24.

Fleisher, C. S., Stephan, A. R., and Miner, A. 1997. Anatomy of a first-time internal- process benchmarking project: Operation, contrasts \& lessons. Competitive Intelligence Review 8(2): 44-57.

Fleisher, C. S. 1999. Public policy Competitive Intelligence. Competitive Intelligence Review 10(2): 23-36.

Francis, D. B., and Herring, J. P. 1999. Key intelligence topics: A window on the corporate competitive psyche. Competitive Intelligence Review 10(4): 10-19.

Fraser, V., Marcella, R., and Middleton I. 2000. Employee perceptions of knowledge sharing: Employment threat or synergy for the greater good? A case study. Competitive Intelligence Review 11(2): 39-52.

Gieskes, H. 2000. Competitive intelligence at LEXIS-NEXIS. Competitive Intelligence Review 11(2): 4-11.

Hamilton, L. L. 1997. Raising the bar of professionalism. Competitive Intelligence Review 8(3): 37.

Hamrefors, S. 1998. Spontaneous environmental scanning. Competitive Intelligence Review 9(3): 68-75.

Harkleroad, D. 1998. Ostriches and eagles II. Competitive Intelligence Review 9(1): 13-19.

Hlebe Trevino, L., and Weaver, G. R. 1997. Ethical issues in competitive intelligence practice: Consensus, conflicts, and challenges. Competitive Intelligence Review 8(1): 61-72.

Home, M. 1999. Competitive Intelligence in the business valuation profession: A case study. Competitive Intelligence Review 10(3): 3342.

Horowitz, R. 1998. The Economic Espionage Act: The rules have not changed. Competitive Intelligence Review 9(3): 30-38.

Hrol, T. F., Coleman, J. C., and Bryant P. J. 1996. Competitive technical intelligence and commercial decision making. Competitive Intelligence Review 7(1): 28-37.

Lackman, C. L., Saban, K., and Lanasa, J. M. 2000. Organizing the competitive intelligence function: A benchmarking study. Competitive Intelligence Review 11(1): 1727.

Lisse, W. C. 1998. The economics of information and the internet. Competitive Intelligence Review 9(4): 48-55.

Marin-Llanes, L., Carro-Cartaya, J., and EspinAndrade, R. 2001. Information analysis techniques for the competitive intelligence process. Competitive Intelligence Review 12(1): 32-40.

Mohinder, D. 1998. CI product line: A tool for enhancing user acceptance of CI. Competitive Intelligence Review 9(2): 17-25.

Ogilvie, T. J. 1997. The theory of the case: What prosecutors can teach us about competitive 
intelligence. Competitive Intelligence Review 8(2): 12-19.

Pattakos, A. N. 1997. Keeping company secrets secret. Competitive Intelligence Review 8(3): 71-78.

Peabody, N. H. 1997. Face to face: Getting international ci through in-person interviews. Competitive Intelligence Review 8(1): 24-32.

Pettersson, U. 2001. Creating an intelligence system at the Swedish National Financial Management Authority. Competitive Intelligence Review 12(2): 20-31.

Prior, V. 1996. Intelligence Reports: Stimulating executive action. Competitive Intelligence Review 7(1): 62-64.

Prior, V. 1996. Trade shows and exhibitions: The intelligence Gatherer's cornu. Competitive Intelligence Review 7(4): 77-78.

Prior, V. 1997. Education and CI: Are he pulling the toil homer than patting the head?. Competitive Intelligence Review 8(2): 93-94.

Prior, V. 1998. The language of competitive intelligence: Part three. Competitive Intelligence Review 9(4): 84-86.

Reibstein, D. J., and Chussil, M. J. 1999. Putting the lesson before the test: Using simulation to analyze and develop competitive strategies. Competitive Intelligence Review 10(1): 3448.

Rühli, E., and Sachs, S. 1997. Challenges for strategic competitive intelligence at the corporate level. Competitive Intelligence Review 8(4): 54-64.

Sandman., M. A. 1997. Confidentiality, CI, and the IBM patent server. Competitive Intelligence Review 8(4): 85-86.

Sawka, K. A. 1997. Competitive intelligence analysis: Filling the corporate analytic void. Competitive Intelligence Review 8(1): 87-89.

Sawyer, D. C. 1997. Customer ritual as a competitive threat. Competitive Intelligence Review 8(2): 83-84.
Sawyer, D. C. 1997. Customer life stage as a competitive threat. Competitive Intelligence Review 8(3): 87-88.

Serpa., L. F. 2000. Epistemological assessment of current business intelligence archetypes. Competitive Intelligence Review 11(4): 88101.

Shaker, S. M., and Kardulias, G. 1996. Scoring at conferences: The quarterback technique for gathering intelligence. Competitive Intelligence Review 7(4): 4-10.

Simon, N. J. 1996. Meeting the challenge of change: The issue of readiness. Competitive Intelligence Review 7(2): 86-88.

Simon, N. J. 1996. Gaining organizational sponsorship. Competitive Intelligence Review 7(3): 80-82.

Simon, N. J. 1996. Creating constructive alliances for a successful CI unit. Competitive Intelligence Review 7(4): 86-87.

Simon, N. J. 1997. CI is not an island. Competitive Intelligence Review 8(4): 80-82.

Stedman, M. J. 1996. Looking inward: Competitive intelligence as a focus for benchmarking and reengineering at Avon. Competitive Intelligence Review 7(1): 4-8.

Underwood, J. 1998. Perspectives on war gaming. Competitive Intelligence Review 9(2): 46-52.

Watts, R. J., Porter, A. L., and Newman, N. C. Innovation forecasting using bibliometrics. Competitive Intelligence Review 9(4): 11-19.

Walle, A. H. 1999. Corporate configurations and Competitive Intelligence: Understanding organizations at a distance. Competitive Intelligence Review 10(4): 55-64.

Wang, C. K. 2001. Organizational competence analysis: Experience of a Japanese multinational. Competitive Intelligence Review 12(3): 3-9.

Zanasi, A. 1998. Competitive intelligence through data mining public sources. Competitive Intelligence Review 9(1): 44-54. 